Article

\title{
Diverse Outcomes: Social Citizenship and the Inclusion of Skilled Migrants in Australia
}

\author{
Juliet Pietsch \\ School of Politics and International Relations, Australian National University, Canberra, ACT 0200, Australia; \\ E-Mail: juliet.pietsch@anu.edu.au
}

Submitted: 24 September 2016 | Accepted: 8 February 2017 | Published: 28 March 2017

\begin{abstract}
The sociology of citizenship is concerned with the social and economic conditions of citizens of a national community. Drawing on T. H. Marshall's contribution to the theory of social citizenship this article argues that some groups of migrants and ethnic minorities in Australia, particularly those from non-British and European Backgrounds, face a number of social and institutional barriers which prevent them from reaching their full potential as members of Australia's multicultural community. Evidence from the Australian Bureau of Statistics Census data shows different socioeconomic outcomes for migrants from British and European backgrounds compared with migrants from Asian backgrounds, despite having similar educational qualifications and length of time living in Australia. As such, it is argued that achieving social membership and inclusion continues to be a struggle for particular groups of migrants. A deeper commitment to the core principles of citizenship that is beyond mere notions of formal equality is needed if Australia is to address this important social issue.
\end{abstract}

\section{Keywords}

Australia; inclusion; migrants; social citizenship; socioeconomic status

\section{Issue}

This article is part of the issue "International Migration and Ethnic Integration", edited by Yaojun Li (University of Manchester, UK) and Anthony Heath (University of Oxford, UK).

(C) 2017 by the author; licensee Cogitatio (Lisbon, Portugal). This article is licensed under a Creative Commons Attribution 4.0 International License (CC BY).

\section{Introduction}

Social theorists have long been interested in the concept of citizenship which links individual entitlement on the one hand and ideas and attachment to a particular community on the other (Kymlicka \& Norman, 1994). Debates about citizenship and multiculturalism are often sparked by social or political events or crises, which bring to the fore perceptions of weak ties among a particular racial, ethnic or religious group to the nation. For example, following the 9/11 terrorist attacks in the United States and Europe's 2015 refugee crisis, numerous political leaders around the world have denounced multiculturalism as a failure, and have instead emphasised the need for migrants to demonstrate their loyalty to the laws, values and traditions of their country. The resurgence of support for far-right wing parties and other populist representatives in the West demonstrates the grow- ing amount of pressure on governments to withdraw from progressive and inclusive social citizenship policies for new migrants.

In order to enjoy full membership, members of migrant and ethnic minority groups have frequently had to adopt the majority culture through societal pressures to assimilate. Some groups have found this easier than others due to cross-cultural differences in terms of language, culture, political background and religion. Drawing on theories of social citizenship, this research shows that since the 1990s there is evidence of differential socioeconomic outcomes for European and non-European migrants in Australia, particularly in terms of income and professional employment opportunities relative to education. In doing so, this research looks at whether 'race' in the form of being 'white' or 'non-white' is a barrier to social inclusion. Stephen Castles (2000, p. 41) shows that through a process of social segmentation and social 
exclusion, various migrant and ethnic minority groups tend to remain in disadvantaged labour market positions, which is then passed on to subsequent generations. It is therefore necessary to look at practices of systematic social exclusion, which can lead to social segmentation and differential outcomes for particular groups of migrants and ethnic minority groups.

In Australia, at first glance, the absence of migrants from non-British or European backgrounds is noticeable in leadership positions within national institutions and organisations, suggesting that, even though Australia has adopted a multicultural citizenship model, attitudes of racial and ethnic superiority may continue to pervade Australian institutions and organisations. For example, according to Soutphommasane (2014), the poor representation of Asian Australians in federal politics "appears to replicate a pattern of invisibility that exists within Australian culture". This pattern of invisibility similarly exists in other institutions and organisations, particularly at senior levels where important decisions are often made. While nearly 14 percent of Australians come from nonBritish and European backgrounds, such cultural diversity is not represented within the senior leadership positions in Australian institutions and organisations (AHRC, 2016). This can have flow-on effects in terms of the social exclusion of citizens from migrant backgrounds in shaping the future of Australia. To find out whether social bias and discrimination might be playing a role, using Australian Bureau of Statistics (ABS) Census data between 1970 and 2011, this article examines whether there are any differences in the socioeconomic outcomes of groups that have similar levels of education and have lived in Australia for a similar length of time. First, this article examines theories of social citizenship as a framework for the empirical analysis of the ABS Census data.

\section{Theoretical Background}

The social construction of citizenship in Western democracies which predominantly focuses on the legal and political responsibilities of citizens frequently overlooks the obligations that states have towards their citizens in terms of providing an inclusive social citizenship that addresses the reality of racial inequality and social class. British Sociologist T. H. Marshall divided citizenship into three dimensions, namely civic, political and social rights (Marshall, 1950, 1977, 1981). Social rights were institutionalised in the form of the Welfare state and included a range of social entitlements such as education, health, employment benefits and employment opportunities (Esping-Andersen, 1990). In the incorporation of social rights within the Welfare state, it was argued that citizenship could alter patterns of social inequality. In developing the work of T. H. Marshall, sociologists have since redefined citizenship "as a set of social practices which define the nature of social membership" (Turner, 1993, p. 4). While there are many criticisms of T. H. Marshall's understandings of citizenship such as the fact that it is historically and culturally specific to Western cultures and framed solely within the confines of the nationstate (Barbalet, 1988; Hindess, 1993; Janoski, 1998; King \& Waldron, 1988; Ong, 2005), there is no doubt that in Western democracies groups of citizens with civil and political rights are denied basic social rights such as equality of opportunity, employment and income due to various forms of discrimination and racial prejudice.

In culturally plural societies, migrants and ethnic minorities struggle to attain full membership and social inclusion. Talcott Parsons originally defined social inclusion as the process by which previously excluded groups attain full citizenship or membership in a society (Parsons, 1994, p. 145). Since then, studies have shown a multidimensional approach to understanding full membership and social inclusion. The World Bank (2007) for instance defines social inclusion in terms of financial, physical, human and social capital and emotional and functional satisfaction. Other studies define social inclusion in terms of material resources, social relations, civic activities, basic services, neighbourhood inclusion, achievement, participation and social connection (Greef, Verté, \& Segers, 2015; Ogg, 2005). Migrants and ethnic minorities can be denied social inclusion due to their cultural background, linguistic differences, political or religious background or the distance between their country of origin and host country (see Dahlstedt \& Bevelander, 2010). This article further looks at social inclusion in terms of income and occupational status opportunities, both of which can impact on leadership opportunities and levels of autonomy within an organisation. To be a full member in society, migrants and ethnic minorities need to have opportunities to not only participate in society but also shape the future of a society by utilising their various strengths and skills.

One of the significant barriers for migrants and ethnic minorities is the growing demands for linguistic assimilation in terms of English or national language proficiency, accent, style and pronunciation which some researchers have viewed as a form of racial discrimination (Colic-Peisker, 2005; Creese \& Kambere, 2003; Hill, 2008; Piller \& Takahashi, 2011). In fact, Piller and Takahashi (2011, p. 371) observe that "social inclusion policies are often blind to the ways in which language proficiency and language ideologies mediate social inclusion in linguistically diverse societies". For instance, in Australia and in other diverse multicultural societies, migrants and ethnic minorities wishing to attain citizenship must demonstrate English language proficiency in the form of passing a citizenship test written in English. This is just one hurdle towards full membership. In applying for a professional job or a position of leadership, some groups of migrants and ethnic minorities also need to overcome social bias due to their place of birth, skin colour, distinctive accent, etc. While place of birth is not always known, visible and audible markers such as skin colour and accent are often used as replacements for social bias (see McCrone $\&$ Bechhofer, 2008). For those with minority group as- 
cribed characteristics, social inclusion and full membership may become an unreachable goal unless the majority accepts various forms of ascribed cultural and linguistic diversity as equal.

\section{Citizenship and Social Inclusion}

Together with formal modes of citizenship, socioeconomic achievement relative to opportunity is a necessity for the social inclusion and full membership of migrant and ethnic minority groups. Despite detecting a general pattern of upward socioeconomic mobility over time, research finds that some migrant and ethnic minority groups are less likely to experience upward socioeconomic mobility over time than others, thus providing evidence of social exclusion. In fact, in some cases, they may experience downward mobility because of a number of social and institutional barriers (Basran \& Zong, 1998). A number of reasons emerge from research into the experience of migrants to explain these disparities. First, some areas of the labour market could be influenced by direct and indirect discrimination (Fox, 2013). In these areas, dominant groups in society exclude other groups from positions of influence. Weber (1978) referred to this phenomenon as a form of 'social closure', whereby one group excludes the other from scarce resources, and in doing so, is able to maintain the dominant group's privilege and social position.

Research evidence suggests that across Western migrant societies, race and birthplace origins can have an effect on whether or not some groups will experience upward socioeconomic mobility (Bauder, 2003; Frank, 2013; Valtonen, 2001; Weedon, 2002). This has been shown to be the case for 'non-white' ethnic minorities who, despite having very high levels of education, are particularly vulnerable to social exclusion. For example, with an overall shift from unskilled to skilled migration, higher levels of socioeconomic status as well as access to professional and managerial occupations are to be expected among first-generation migrants, thus negating the traditional pattern of overall income increase in later generations. However, this assumes that new skilled migrants do not face direct or indirect discrimination in the workforce. Inglis and Model (2007) find that, in contrast to people with European ancestry, 'non-white' migrants and ethnic minorities often remain disadvantaged for several generations. To examine whether there is a pattern of this occurring in Australia, in the next section this article examines the socioeconomic outcomes of Asian and European migrants with similar education backgrounds and length of stay in Australia. All things being equal, it is expected that both groups should have similar outcomes in terms of income and occupational status.

\section{Diverse Entry Outcomes for Skilled Migrants}

First, it is important to look at overall migration patterns in Australia in order to establish a contextual understand- ing of the diverse socioeconomic outcomes of different groups of migrants in Australia. Results from the ABS Census in Figure 1 show that over time the patterns of migration from the United Kingdom have remained fairly steady, with very little change over four decades of expansive immigration programs. However, as a proportion of the overseas-born population, their numbers have steadily declined from 41 percent of the overseasborn population in 1976 to 21 percent in 2011. There has been a similar pattern of steady immigration from other parts of Europe. However, since the 1970s, the proportion of Australia's overseas-born population in each major European group has declined. The sharpest declines in the proportion of the overseas-born population have been from the United Kingdom, Italy, former Yugoslavia, and Greece. For example, the Italian-born now comprise three percent of the Australian overseas-born population, compared with 11 percent in 1971; the Greek-born now comprise two percent of the Australian overseasborn population, compared with six percent in 1976. The decline in European migration is partly attributed to economic growth in Europe, which has rendered emigration to Australia less attractive than in the immediate postwar period.

The pattern of migration of people born in Asian countries has moved in the opposite direction. For instance, Figure 1 shows the exponential rise in numbers of migrants from Asian countries. Much of this increase can be attributed to the rapid growth in migration from China and India. As a proportion of Australia's overseas-born population, the Chinese-born population has increased from less than one percent in 1971 to six percent in 2011 (see Table 1). One of the contributing factors to this increase was the Australian government's decision to grant temporary and permanent residency status to students from the People's Republic of China in the aftermath of the Tiananmen Square protests of 1989, which then brought their family members to Australia through the family reunion scheme. The Indian-born population has similarly increased from one percent of the overseasborn population in 1971 to six percent in 2011 (see Table 1). Overall, in 2011 migrants born in Asian countries comprised 37 percent of the overseas-born population of Australia, not far behind the numbers of Europeanborn migrants, who made up 40 percent of the overseasborn population. In Table 1 it can be seen that within the Asian group the top source countries are China, India, Vietnam, Philippines and Malaysia.

In terms of Australia's population more broadly, the results in Table 2 show the overall birthplace origins of the Australian population. The findings show that Australia's migrant population is much more diverse than in the 1970s when the majority of migrants came from the United Kingdom or countries in Europe. In recent times, Australia continues to accept significant numbers of United Kingdom and European migrants, however, there has been a significant increase in the numbers of migrants from Asia (up to 9.2 percent in 2011) and other 


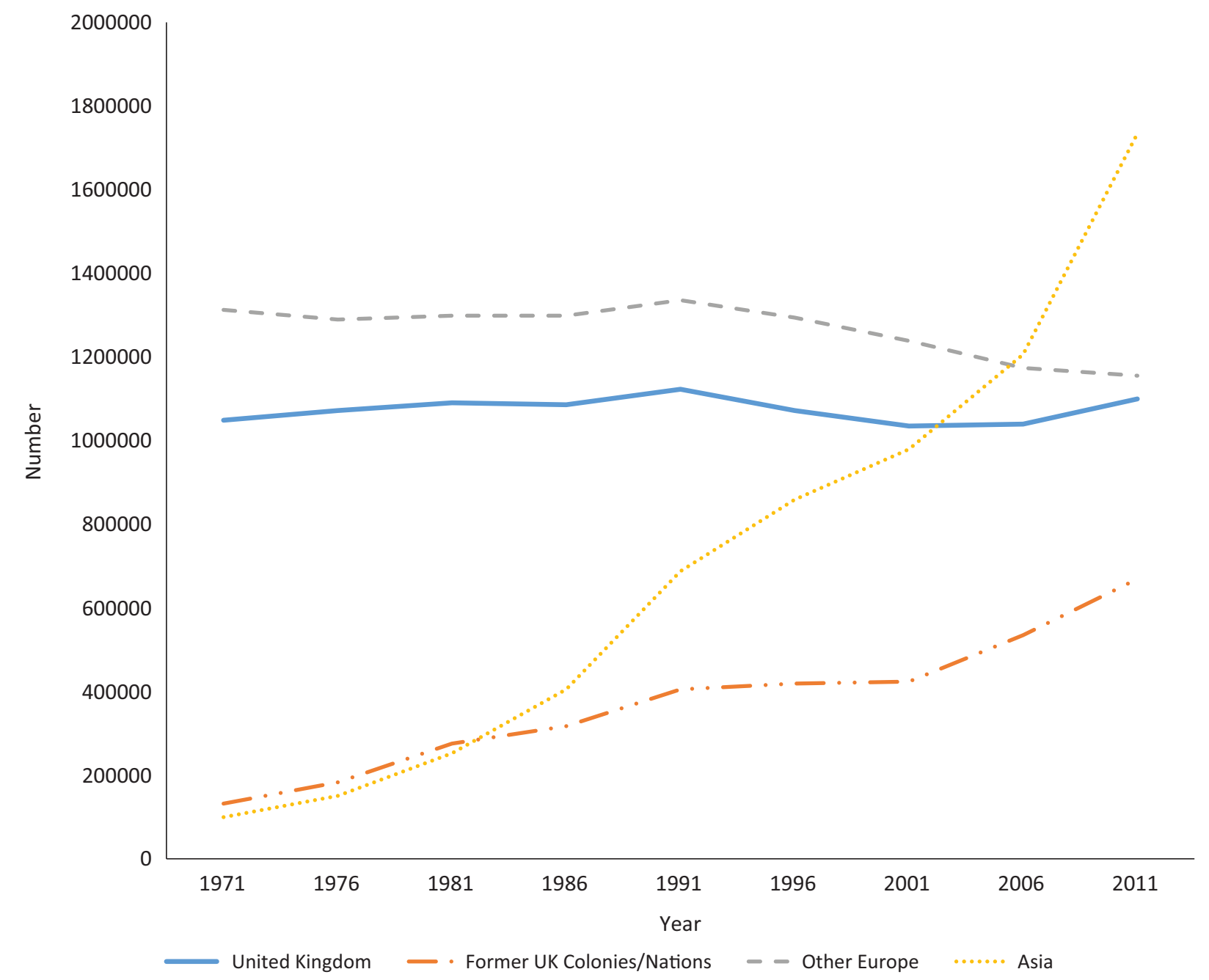

Figure 1. Population of migrants born overseas in Australia, 1971-2011.

Table 1. Population of migrants to Australia from main source countries in Asia, percent, 1971-2011.

\begin{tabular}{|c|c|c|c|c|c|c|c|c|c|}
\hline & 1971 & 1976 & 1981 & 1986 & 1991 & 1996 & 2001 & 2006 & 2011 \\
\hline China & 0.7 & 0.7 & 0.9 & 1.2 & 2.1 & 2.9 & 3.5 & 4.7 & 6.0 \\
\hline India & 1.1 & 1.4 & 1.4 & 1.5 & 1.6 & 2.0 & 2.3 & 3.3 & 5.6 \\
\hline Vietnam & 0.0 & 0.1 & 1.4 & 2.6 & 3.3 & 3.9 & 3.8 & 3.6 & 3.5 \\
\hline Philippines & 0.1 & 0.2 & 0.5 & 1.0 & 2.0 & 2.4 & 2.5 & 2.7 & 3.2 \\
\hline Malaysia & 0.6 & 0.8 & 1.1 & 1.5 & 1.9 & 2.0 & 1.9 & 2.1 & 2.2 \\
\hline Sri Lanka & 0.0 & 0.6 & 0.6 & 0.7 & 1.0 & 1.2 & 1.3 & 1.4 & 1.6 \\
\hline Korea & 0.0 & 0.1 & 0.2 & 0.3 & 0.6 & 0.8 & 0.9 & 1.2 & 1.4 \\
\hline Indonesia & 0.3 & 0.4 & 0.4 & 0.5 & 0.9 & 1.1 & 1.1 & 1.2 & 1.2 \\
\hline $\begin{array}{l}\text { Total } \\
\text { Overseas- } \\
\text { Born } \\
\text { Population (n) }\end{array}$ & $2,578,963$ & $2,608,109$ & $3,003,798$ & $3,247,423$ & $3,756,441$ & $3,876,709$ & $4,105,637$ & $4,416,029$ & $5,294,150$ \\
\hline
\end{tabular}

regions including the Middle East, Africa and the Pacific Islands (up to 7.4 percent in 2011).

So far, the Census data shows that Australia's racial and ethnic make-up is gradually changing over time with an increase in migrants from non-British and European backgrounds, many of whom might be classified as 'non- white' in North American or British classification systems. In Australia, it is difficult to accurately measure the numbers of 'non-white' migrants and ethnic minorities beyond the first-generation because in the Census the Australian-born are only asked if they have parents born overseas and not where their parents come from. 
Table 2. Birthplace origins of the Australian population, percent, 1971-2011.

\begin{tabular}{|c|c|c|c|c|c|c|c|c|c|}
\hline & 1971 & 1976 & 1981 & 1986 & 1991 & 1996 & 2001 & 2006 & 2011 \\
\hline Australia & 79.8 & 80.6 & 78.2 & 77.6 & 75.5 & 74.5 & 72.6 & 70.9 & 69.8 \\
\hline United Kingdom & 8.2 & 8.0 & 7.5 & 6.9 & 6.7 & 6.0 & 5.5 & 5.2 & 5.1 \\
\hline $\begin{array}{c}\text { Former UK } \\
\text { Colonies/ } \\
\text { Nations }\end{array}$ & 1.0 & 1.4 & 1.9 & 2.0 & 2.4 & 2.4 & 2.3 & 2.7 & 3.1 \\
\hline Other Europe & 10.3 & 9.6 & 8.9 & 8.3 & 7.9 & 7.3 & 6.6 & 5.9 & 5.4 \\
\hline Asia & 0.8 & 1.1 & 1.7 & 2.6 & 4.1 & 4.8 & 5.2 & 6.1 & 9.2 \\
\hline Other & & & 1.9 & 2.5 & 3.4 & 5.0 & 7.8 & 9.2 & 7.4 \\
\hline $\begin{array}{l}\text { Total } \\
\text { Australian } \\
\text { population (n) }\end{array}$ & $(12,755,620)$ & $(13,437,725)$ & $(14,576,294)$ & $(15,602,198)$ & $(16,850,288)$ & $(17,752,874)$ & $(18,769,240)$ & $(19,855,287)$ & $(21,507,719)$ \\
\hline
\end{tabular}

However, the Census includes a question about ancestry among the Australian-born and those born overseas. In looking at the results in Table 3, the figures show that 0.9 percent of the Australian-born and up to 33 percent of first-generation migrants identify as having an Asian, Middle Eastern or Sub-Saharan African ancestry of which most (though not all) could be classified as 'non-white'. Overall, the Asian pan-ethnic group represent the fastest growing 'non-white' group in Australia. As such the remainder of this article focuses on the experiences of Asian migrants in particular and compares their experiences with migrants from the United Kingdom and other parts of Europe, of whom the majority in Australia have British or European ancestry.

In order to demonstrate the diverse socioeconomic outcomes among European and Asian first-generation migrants in Australia, the following results present comparisons in education, income and occupation of three separate migrant cohorts from the United Kingdom, Europe and Asia. Table 4 reveals that a higher proportion of migrants from Asia than from other countries hold a bachelor or postgraduate degree, which could be attributed to the fact that a greater proportion of recent migrants to Australia are arriving as highly skilled migrants who have met the requirements of the competitive points system. Nevertheless, even when the education levels of Asian migrants before the 1990s are taken into account, it is apparent that migrants from Asia are more likely to hold a university qualification than migrants from other countries. More than 28 percent of Asian migrants within each of the migration waves other than Vietnam hold a university qualification (see Table 4). A smaller proportion of migrants born in the United Kingdom and Europe arriving in the migration wave before the 1990s hold university degrees.

Given the higher levels of educational attainment among migrants born in Asia, one would expect there to be a higher proportion of Asian migrants than European migrants in high-income professional occupations, particularly among those groups who arrived before the 1990s. However, the findings in Figure 2 show diverse outcomes for two groups from different regions with a

Table 3. First mentioned ancestry origins of the Australian population, 2011.

\begin{tabular}{lrrrr}
\hline & \multicolumn{2}{c}{ Born in Australia } & \multicolumn{2}{c}{ Born Overseas } \\
\cline { 2 - 5 } & \multicolumn{1}{c}{$(\mathrm{n})$} & $(\%)$ & $(\mathrm{n})$ & $(\%)$ \\
\hline Oceanian & $(4,592,267)$ & 37.5 & $(581,983)$ & 7.4 \\
North-West European & $(6,774,794)$ & 55.3 & $(3,051,313)$ & 38.6 \\
Southern and Eastern European & $(467,499)$ & 3.8 & $(1,330,608)$ & 16.8 \\
North African and Middle Eastern & $(43,850)$ & 0.4 & $(409,155)$ & 5.2 \\
South-East Asian & $(7,285)$ & 0.1 & $(525,321)$ & 6.6 \\
North-East Asian & $(35,675)$ & 0.3 & $(894,412)$ & 11.3 \\
Southern and Central Asian & $(7,966)$ & 0.1 & $(627,908)$ & 7.9 \\
Peoples of the Americas & $(7,049)$ & 0.1 & $(118,184)$ & 1.5 \\
Sub-Saharan African & $(3,560)$ & 0.0 & $(149,927)$ & 1.9 \\
Other & $(16,203)$ & 0.1 & $(45,481)$ & 0.6 \\
Not Stated & $(291,698)$ & 2.4 & $(166,895)$ & 2.1 \\
\hline Total overseas born $(\mathrm{n})$ & $(12,247,846)$ & 100 & $(7,901,187)$ & 100 \\
\hline
\end{tabular}

Source: ABS (2011a). 
Table 4. Migrants in Australia with a university education, by year of arrival, percent.

\begin{tabular}{|c|c|c|c|c|}
\hline & $<1990 s$ & 1991-2000 & 2001-2011 & (n) \\
\hline \multicolumn{5}{|l|}{ UK } \\
\hline England & 20 & 30 & 22 & $(125,778)$ \\
\hline Scotland & 18 & 32 & 27 & $(16,388)$ \\
\hline Wales & 23 & 36 & 31 & $(4,692)$ \\
\hline Northern Ireland & 21 & 42 & 34 & $(3,366)$ \\
\hline \multicolumn{5}{|l|}{ Other Europe } \\
\hline Italy & 5 & 21 & 24 & $(7,300)$ \\
\hline Former Yugoslavia & 6 & 17 & 12 & $(12,493)$ \\
\hline Germany & 14 & 28 & 26 & $(11,016)$ \\
\hline Greece & 5 & 11 & 9 & $(4,328)$ \\
\hline Netherland & 12 & 31 & 23 & $(7,061)$ \\
\hline Ireland & 22 & 37 & 29 & $(8,535)$ \\
\hline Poland & 23 & 37 & 48 & $(10,655)$ \\
\hline Malta & 4 & 14 & 12 & $(1,494)$ \\
\hline \multicolumn{5}{|l|}{ Asia } \\
\hline China & 28 & 41 & 48 & $(54,866)$ \\
\hline India & 36 & 58 & 60 & $(66,376)$ \\
\hline Vietnam & 20 & 13 & 17 & $(25,532)$ \\
\hline Philippines & 38 & 34 & 36 & $(40,418)$ \\
\hline Malaysia & 48 & 47 & 38 & $(25,815)$ \\
\hline Sri Lanka & 34 & 40 & 40 & $(19,974)$ \\
\hline Korea & 40 & 42 & 32 & $(10,901)$ \\
\hline Indonesia & 31 & 44 & 37 & $(8,445)$ \\
\hline
\end{tabular}

Source: ABS (2011a).

similar education and period of arrival in Australia indicating that for some groups there might be barriers to reaching their full potential. In terms of income, for those who have lived in Australia since before the 1990s, the outcomes for Asian migrants and migrants from the United Kingdom are fairly similar, showing that over time Asian migrants eventually catch up to other groups and even overtake other groups such as those from other parts of Europe.

For new migrants, the story is very different. New migrants from the United Kingdom tend to receive a much greater return on their education than new migrants from Asia. Over 30 percent of recent arrivals from the United Kingdom are employed in the highestincome bracket. The proportions of new migrants from Asian countries in the highest-income bracket are much smaller, with only 14 percent of Asian migrants in the highest-income bracket. It is possible that the differences in entry earnings capacity among recent Asian cohorts could be explained by the heightened emphasis on English language ability. However, given that skilled migrants from Asia, especially those with a university education, are usually fluent in English, this is less likely to explain the variation. Instead, it is more likely that other factors could be playing a role such as skin colour, accent or simply employer-based discrimination.

Another explanation might be related to the fact that many Asian migrants are students without Australian cit- izenship. However, while the majority of overseas students from Asia do not have citizenship, the results in Figure 2 only look at the experiences of migrants with citizenship. In looking at whether there are differences among those with citizenship and those without citizenship, the results in Figure 3 show that a higher proportion of new migrants from the United Kingdom and other parts of Europe earn a high income compared to the Asian cohort. Only six percent of recent arrivals from Asia without citizenship earn a high income compared to 28 percent of those from the United Kingdom and 19 percent of those from other parts of Europe. Asian migrants who arrived before 1990 end up doing comparatively better but it appears that it takes longer to achieve similar or better outcomes in terms of income status than their European counterparts.

The differences in outcomes might be explained by a number of other factors. For example, it is possible that the earlier cohort of Asian migrants to Australia who arrived before 1990 came from different origin countries than those who have arrived later. For example, we might expect those from English-speaking Hong Kong to have better outcomes than recent arrivals from non-English speaking countries in Asia. There are also likely to be differences among those from Englishspeaking Northern European countries and those from non-English speaking European countries in Southern and Eastern Europe. To explore this in a more detail, a re- 


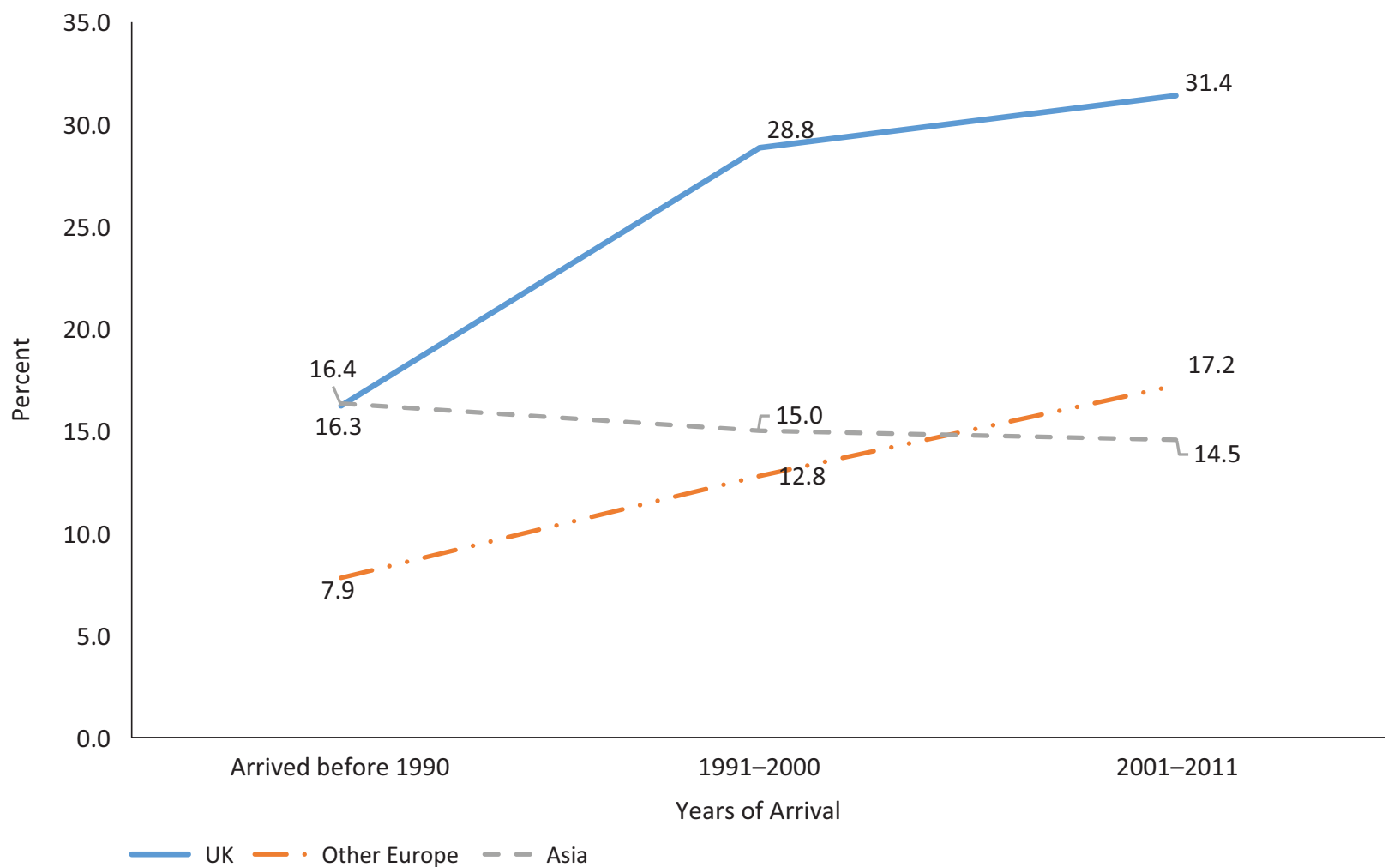

Figure 2. Percentage of migrant citizens on high incomes by year of arrival.

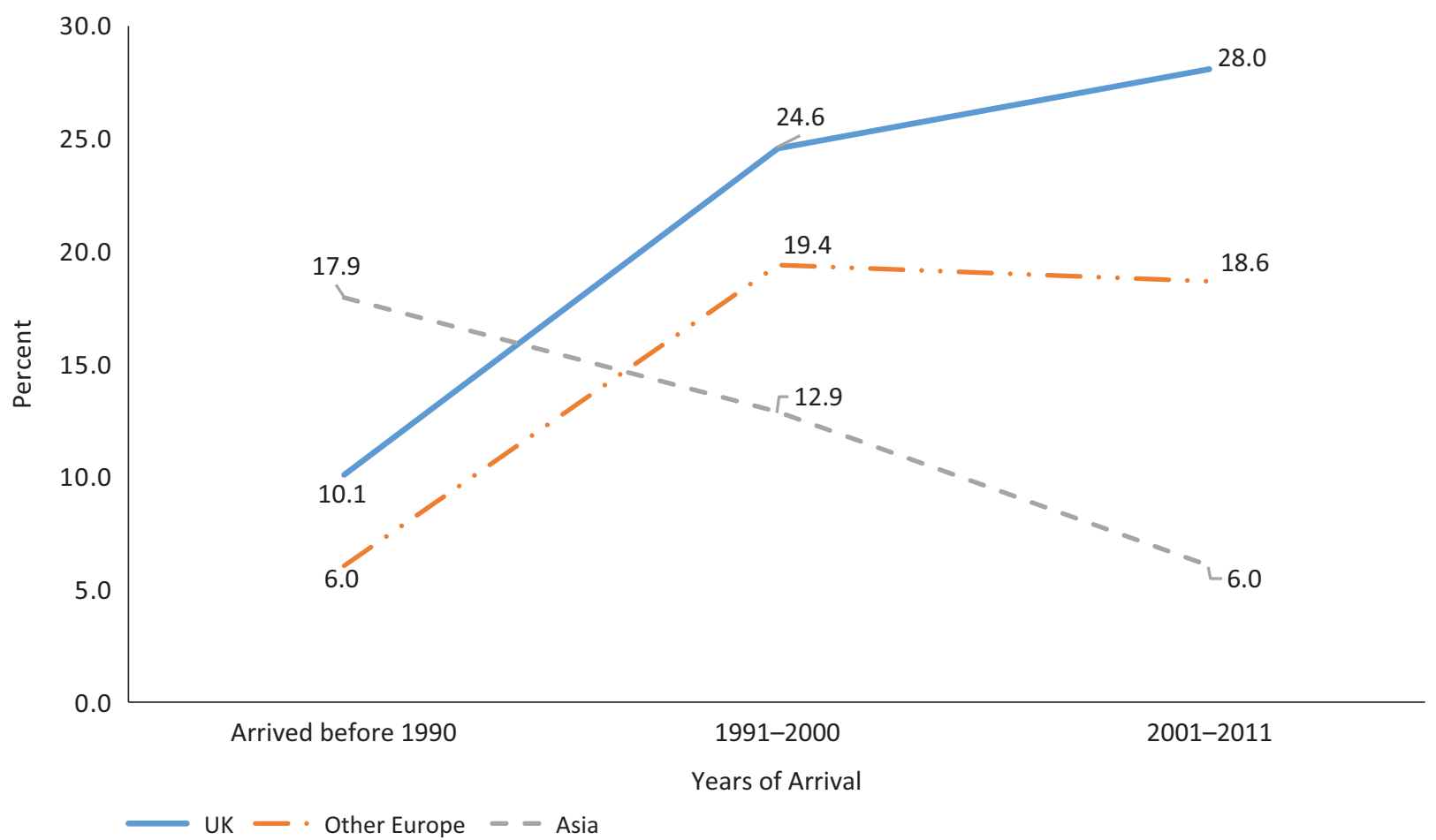

Figure 3. Percentage of migrants without citizenship on high incomes by year of arrival.

gression analysis is conducted to control for background factors such as English proficiency, timing of arrival, age, education, gender and citizenship status to determine whether there is a correlation between country origins and income status.
Table 5 draws on a sample from the 2011 Census, which is provided in the confidential unit record files (CURFs) and is based on a one percent sample of the Census population. The effects of country origins and timing of arrival is clearly evident in the multivariate results 
shown in Table 5. In terms of birthplace, migrants from South Asia and North-East Asia, as well as Southern and Eastern Europe, are less likely to earn a high income compared to migrants from the United Kingdom and Northern Europe. Newer arrivals are also less likely to earn a high income compared to migrants from previous migration waves, as the earlier findings demonstrate.

Up to 45 percent of the total sample of South Asians and 70 percent of new arrivals from South Asia have completed a bachelor degree or higher such as a postgraduate degree. This compares with 38 percent of the total sample of North-East Asians and 70 percent of new arrivals from North-East Asia. Among the total sample of
Northern Europeans, only 24 percent have completed a bachelor degree or higher and among the new arrivals from the Northern Europe only 55 percent have completed a bachelor degree or higher. This is significantly less than the proportions of those with a bachelor degree or higher from South Asia and North-East Asia (70 percent). With such differences in the percentage of those with university education qualifications between those from Asia and those from Northern Europe, one would expect a positive relationship between Asian country origins and income status. Instead, the opposite is the case, indicating the possible existence of racial or ethnic discrimination.

Table 5. OLS Regression Model estimating effects of origins and background on income, Census, 2011.

\begin{tabular}{|c|c|c|c|}
\hline & (B) & $(\beta)$ & Sig. \\
\hline Constant & 2.61 & & 0.00 \\
\hline \multicolumn{4}{|l|}{ Birthplace } \\
\hline South-Asia & -0.68 & -0.09 & 0.00 \\
\hline North-East Asia & -1.22 & -0.16 & 0.00 \\
\hline South-East Asia & -0.04 & -0.01 & 0.86 \\
\hline Southern and Eastern Europe & -0.67 & -0.07 & 0.00 \\
\hline \multicolumn{4}{|l|}{ Ancestry of Parent 1} \\
\hline Southern and Central Asia & 0.27 & 0.04 & 0.14 \\
\hline North-East Asia & 0.26 & 0.04 & 0.26 \\
\hline South-East Asia & 0.39 & 0.04 & 0.10 \\
\hline Southern and Eastern Europe & 0.35 & 0.04 & 0.03 \\
\hline \multicolumn{4}{|l|}{ Ancestry of Parent 2} \\
\hline Southern and Central Asia & -0.17 & -0.01 & 0.56 \\
\hline North-East Asia & -0.38 & -0.01 & 0.33 \\
\hline South-East Asia & 0.68 & 0.02 & 0.01 \\
\hline Southern and Eastern Europe & -0.07 & 0.00 & 0.76 \\
\hline \multicolumn{4}{|l|}{ Language Spoken at Home } \\
\hline Southern Asian Languages & 0.44 & 0.06 & 0.03 \\
\hline Eastern Asian Languages & 0.59 & 0.08 & 0.04 \\
\hline South-East Asian Languages & -0.10 & -0.01 & 0.73 \\
\hline Southern European languages & 0.55 & 0.07 & 0.00 \\
\hline Northern European Languages & 1.28 & 0.10 & 0.00 \\
\hline \multicolumn{4}{|l|}{ English Proficiency } \\
\hline Very Well or Well & 1.44 & 0.12 & 0.00 \\
\hline \multicolumn{4}{|l|}{ Timing of Arrival } \\
\hline Arrived 2000 or before & 1.02 & 0.17 & 0.00 \\
\hline Arrived 2001-2005 & 0.71 & 0.08 & 0.00 \\
\hline \multicolumn{4}{|l|}{ Background } \\
\hline Age & -0.09 & -0.09 & 0.00 \\
\hline Education & 0.53 & 0.23 & 0.00 \\
\hline Gender & 1.37 & 0.22 & 0.00 \\
\hline Citizenship & 0.84 & 0.13 & 0.00 \\
\hline $\begin{array}{l}\text { Adjusted } \mathrm{R}^{2} \\
\mathrm{~N}\end{array}$ & $\begin{array}{c}0.18 \\
(11,979)\end{array}$ & & \\
\hline
\end{tabular}

Source: ABS (2011b). ( $\mathrm{N}=11,979)$. B: Unstandardised regression coefficient. $\beta$ : Standardised regression coefficient. See Table A.1 in the Appendix for coding of variables. 
In terms of occupational status, Table 6 finds a similar outcome. Given that a higher percentage of migrants from Asia in the CURF sample have a university education compared to migrants from Northern Europe, one might expect a higher percentage of migrants from Asia to be employed in a professional occupation. However, the findings in Table 6 indicate the opposite to be the case with a negative relationship between South Asian and North-East Asian birthplace origins and professional occupation status. For instance, the odds ratios (Exp (B)) are less than 1 , showing that those from South Asia and North-East Asia are less likely to be employed as professionals compared to those from Northern Europe, even after controlling for language spoken at home, English proficiency, timing of arrival, education, age and citizenship status. The odds ratios are also highly significant (sig.=.000). This pattern suggests that migrants from the United Kingdom and Northern Europe, despite having lower levels of educational attainment, are more easily able to move into high-income professional occupations shortly after their arrival in Australia.

\section{Discussion}

The findings presented reveal that there are several barriers to a high income and occupational status among new

Table 6. Logistic Regression Model estimating effects of origins and background on occupation, census, 2011.

\begin{tabular}{|c|c|c|c|c|}
\hline & B & SE & Sig. & $\operatorname{Exp}(B)$ \\
\hline Constant & -4.06 & 0.21 & 0.00 & 0.02 \\
\hline \multicolumn{5}{|l|}{ Birthplace } \\
\hline South-Asia & -0.93 & 0.14 & 0.00 & 0.40 \\
\hline North-East Asia & -0.70 & 0.23 & 0.00 & 0.50 \\
\hline South-East Asia & -0.12 & 0.22 & 0.57 & 0.88 \\
\hline Southern and Eastern Europe & -0.08 & 0.15 & 0.59 & 0.92 \\
\hline \multicolumn{5}{|l|}{ Ancestry of Parent 1} \\
\hline Southern and Central Asia & 0.53 & 0.17 & 0.00 & 1.70 \\
\hline North-East Asia & 0.24 & 0.21 & 0.26 & 1.27 \\
\hline South-East Asia & 0.08 & 0.23 & 0.73 & 1.08 \\
\hline Southern and Eastern Europe & -0.05 & 0.16 & 0.75 & 0.95 \\
\hline \multicolumn{5}{|l|}{ Ancestry of Parent 2} \\
\hline Southern and Central Asia & 0.00 & 0.29 & 0.99 & 1.00 \\
\hline North-East Asia & -0.13 & 0.37 & 0.73 & 0.88 \\
\hline South-East Asia & 0.07 & 0.24 & 0.79 & 1.07 \\
\hline Southern and Eastern Europe & -0.43 & 0.23 & 0.06 & 0.65 \\
\hline \multicolumn{5}{|l|}{ Language Spoken at Home } \\
\hline Southern Asian Languages & 0.03 & 0.19 & 0.89 & 1.03 \\
\hline Eastern Asian Languages & 0.61 & 0.26 & 0.02 & 1.84 \\
\hline South-East Asian Languages & -0.26 & 0.26 & 0.32 & 0.77 \\
\hline Southern European languages & 0.26 & 0.12 & 0.03 & 1.30 \\
\hline Northern European Languages & 0.81 & 0.13 & 0.00 & 2.25 \\
\hline \multicolumn{5}{|l|}{ English Proficiency } \\
\hline Very Well or Well & 1.30 & 0.18 & 0.00 & 3.66 \\
\hline \multicolumn{5}{|l|}{ Timing of Arrival } \\
\hline Arrived 2000 or before & 0.32 & 0.09 & 0.00 & 1.37 \\
\hline Arrived 2001-2005 & 0.21 & 0.08 & 0.01 & 1.24 \\
\hline \multicolumn{5}{|l|}{ Background } \\
\hline Age & 0.02 & 0.01 & 0.11 & 1.02 \\
\hline Education & 0.70 & 0.02 & 0.00 & 2.02 \\
\hline Gender & 0.14 & 0.05 & 0.01 & 1.15 \\
\hline Citizenship & 0.27 & 0.07 & 0.00 & 1.31 \\
\hline Nagelkerke R square & 0.25 & & & \\
\hline $\mathbf{N}$ & 8,386 & & & \\
\hline
\end{tabular}

Source: ABS (2011b). ( $\mathrm{N}=11,979)$. B: Coefficient for the Constant. SE: Standard Error Around the Constant. Exp(B): Odds Ratio. See Table A.1 in the Appendix for coding of variables. 
migrant groups, even for those groups with high levels of education, which result in ethnic labour market segmentation and social exclusion. In terms of income, new migrants from Asia in Australia are less likely to enter professional or managerial positions with a high income than new migrants from Northern Europe. Because the ABS Census survey does not ask whether migrants obtained their educational qualifications in Australia, it is difficult to determine whether there is an issue with the recognition of overseas qualifications or whether racial and ethnic discrimination is affecting the socioeconomic outcomes of migrant groups.

Research in Canada has shown that employers in Canada tend to favour migrants from English-speaking countries with comparable training systems (Hawthorne, 2007). Consequently, 'non-white' ethnic minorities from Asia often find that their skills are either not recognised or devalued. A similar phenomenon occurs in Australia, given that the qualifications and requirements to work in Australia depend on the type of occupation. Assessing overseas qualifications for employment purposes is usually a separate process to applying for a job where, as in all occupations, the employer decides whom they will employ. This tends to ensure that, as in Canada, employers can devalue legitimate qualifications and skills (i.e. human capital) held by 'non-white' migrant and ethnic minorities from Asia.

Comparative research has shown that employers tend to be less inclined to hire a migrant than a locally-born candidate (Heath \& Cheung, 2007; Lindbeck $\&$ Snower, 1988). These forms of discrimination are thought to originate from the idea that people generally identify more with people who look like themselves (Lancee, 2012). For example, in his seminal work, Becker (1971) argued that 'personal preferences' or 'tastes for discrimination' on the part of employers and organisations were the main reasons for labour market discrimination.

In a 2012 study on discrimination in Australia, Booth et al. compared employer attitudes to Anglo Saxon Australians with employer attitudes to Indigenous Australians, Italian Australians, Middle Eastern Australians and Chinese Australians (Booth, Leigh, \& Varganova, 2012). As part of their experiment, the researchers applied for entry-level jobs using distinctively Anglo Saxon, Indigenous Australian, Italian, Chinese and Middle Eastern surnames. Their study found that applications submitted to employers with Anglo Saxon names had a mean callback rate from potential employers of 35 percent. Applications with Italian surnames had a slightly lower callback rate of 32 percent, and those with distinctively Chinese and Middle Eastern surnames had mean callback rates of 21 and 22 percent respectively. Chinese applicants in Sydney hoping to get an interview would have to put in 92 percent more applications than applicants with Anglo Saxon names (Booth et al., 2012, p. 567). Racial and ethnic discrimination, therefore, may prevent highly educated migrants from gaining professional em- ployment opportunities with high incomes and potential leadership opportunities.

Another approach to explain the labour market differences found in this research is to consider social capital theory, which implies that migrants who are equipped with social resources (i.e. social networks and resources of others) perform better in the labour market (Aguilera, 2002; Flap \& Völker, 2004; Franzen \& Hangartner, 2006). Social capital in terms of social networks and the resources of others provides an important gateway into the labour market. One way to further understand the influence of social capital is by distinguishing between 'bonding' and 'bridging' capital (Leonard \& Onyx, 2003; Putnam, 2000; Schuller, 2007; Woolcock \& Narayan, 2000). Bonding capital refers to social networks formed 'within' groups and bridging capital refers to social networks formed 'between' groups. According to Lancee (2012, p. $159)$, the acquisition of bridging capital tends to result in higher income and occupational status whereas the acquisition of bonding capital (such as those formed by established family or co-ethnic networks) does not.

On the surface, it seems that migrants from countries with similar cultural, political and historical ties to Australia's 'white' British and Northern European majority are more quickly and more easily able to transfer their education, skills and experience. This may partly explain why Asian migrants face greater challenges in gaining meaningful employment in line with their educational qualifications, skills, and experience in the initial period after their arrival. It does not, however, explain the whole picture. This is because many Asian migrants have in fact gained appropriate qualifications since arriving in Australia, or hold quality qualifications from internationally recognised higher education institutions in Western democracies. Alternatively, many have been successfully awarded qualification recognition by the Australian government or a peak industry body for holding one or more qualifications from internationally recognised higher education institutions within their own country. However, as mentioned, the requirements to work in Australia depend on the occupation and local employer organisations. The employer alone decides whom they will employ, regardless of the applicant's qualifications and skills. This leaves new migrants highly vulnerable to the attitudes of employers.

In summary, the findings presented suggest that there are a number of barriers to a high socioeconomic status among new migrant groups, even for those groups with high levels of education, which result in racial and ethnic labour market segmentation. In terms of income, new migrants from Asia in Australia are less likely to enter professional and managerial positions with a high income than new migrants from the United Kingdom. Because the ABS Census survey does not ask whether citizens obtained their educational qualifications in Australia, it is difficult to determine whether there is an issue with the employer recognition of foreign qualifications or whether racial and ethnic discrimination is af- 
fecting the socioeconomic outcomes of migrant groups. However, the results do suggest that racial and ethnic discrimination may prevent highly educated migrants from non-British or European backgrounds from gaining professional employment opportunities with high incomes and potential leadership opportunities. It is therefore important to ensure that university-educated and experienced non-British and European migrants are not denied full membership in terms of social citizenship and are able to contribute meaningfully within Australia's leadership ranks and the future direction of the country.

\section{Acknowledgments}

The author would like to thank A/Prof. Christine Inglis (University of Sydney), Emeritus Prof. Anthony Heath (University of Oxford) and the anonymous reviewers for their helpful comments and advice on sections of this paper.

\section{Conflict of Interests}

The author declares no conflict of interests.

\section{References}

Australian Bureau of Statistics. (2011a). Australian Census 2011. Canberra: Australian Bureau of Statistics.

Australian Bureau of Statistics. (2011b). Australian Census 2011. Expanded Confidentialised Unit Record File (CURF), Remote Access Data Laboratory (RADL). Findings based on use of ABS Microdata.

Aguilera, M. (2002). The impact of social capital on labor force participation: Evidence from the 2000 social capital benchmark survey. Social Science Quarterly, 83(3), 854-874.

AHRC. (2016). Leading for change: A blueprint for cultural diversity and inclusive leadership. Sydney. Retrieved from https://www.humanrights.gov.au/our-work/ra ce-discrimination/publications/leading-change-blue print-cultural-diversity-and-inclusive

Barbalet, J. (1988). Citizenship. Milton Keynes: Open University Press.

Basran, G., \& Zong, L. (1998). Devaluation of foreign credentials as perceived by visible minority professional immigrants. Canadian Ethnic Studies, 30(3), 6-22.

Bauder, H. (2003). 'Brain abuse'or devaluation of immigrant labor in Canada. Antipode, 35(4), 699-717.

Becker, G. (1971). The economics of discrimination (2nd ed.). Chicago: Chicago University Press.

Booth, A., Leigh, A., \& Varganova, E. (2012). Does ethnic discrimination vary across minority groups? Evidence from a field experiment. Oxford Bulletin of Economics and Statistics, 74(4), 547-573.

Castles, S. (2000). Underclass or exclusion: Social citizenship for ethnic minorities. In E. Vasta (Ed.), Citizenship, community and democracy (pp. 22-44). London: Palgrave Macmillan.
Colic-Peisker, V. (2005). 'At least you're the right colour': Identity and social inclusion of Bosnian refugees in Australia. Journal of Ethnic and Migration Studies, 31(4), 615-638.

Creese, G., \& Kambere, E. N. (2003). What colour is your English? Canadian Review of Sociology and Anthropology, 40(5), 565-573.

Dahlstedt, I., \& Bevelander, P. (2010). General versus vocational education and employment integration of migrants in Sweden. Journal of Migrant and Refugee Studies, 8(2), 158-192.

Esping-Andersen, G. (1990). The three worlds of welfare capitalism. Cambridge: Polity Press.

Flap, H., \& Völker, B. 2004. Creation and returns of social capital. London: Routledge.

Frank, K. (2013). Immigrant employment success in Canada: Examining the rate of obtaining a job match. International Migration Review, 47(1), 76-105.

Franzen, A., \& Hangartner, D. (2006). Social networks and labor market outcomes: The non-monetary benefits of social capital. European Sociological Review, 22(4), 353-368.

Fox, J. (2013). The uses of racism: Whitewashing new Europeans in the UK. Ethnic and Racial Studies, 36(11), 1871-1889.

Greef, M. D., Verté, D., \& Segers, M. (2015). Differential outcomes of adult education on adult learners' increase in social inclusion. Studies in Continuing Education, 37(1), 62-78.

Hawthorne, L. (2007). Foreign credentials recognition and assessment: An introduction. Canadian Issues, Spring, 3-13.

Heath, A., \& Cheung, S. Y. (Eds.). (2007). Unequal chances: Ethnic minorities in Western labour markets. Oxford: Oxford University Press.

Hill, J. H. (2008). The everyday language of white racism. Malden, MA: Wiley-Blackwell.

Hindess, B. (1993). Citizenship in the modern West. In B. Turner (Ed.), Citizenship and social theory (pp. 19-36). London: SAGE Publications.

Inglis, C., \& Model, S. (2007). Diversity and mobility in Australia. In A. Heath \& S. Y. Cheung (Eds.), Unequal chances: Ethnic minorities in Western labour markets (pp. 45-103). Oxford and New York: Oxford University Press.

Janoski, T. (1998). Citizenship and civil society. Cambridge: Cambridge University Press.

King, D., \& Waldron, J. (1988). Citizenship, social citizenship and the defence of welfare provision. British Journal of Political Science, 18(4), 415-443.

Kymlicka, W., \& Norman, W. (1994). Return of the citizen: A survey of recent work on citizenship theory. Ethics, 104(2), 352-381.

Lancee, B. (2012). Immigrant performance in the labour market: Bonding and bridging social capital. Amsterdam: Amsterdam University Press.

Leonard, R., \& Onyx, J. (2003). Networking through loose and strong ties: An Australian qualitative study. Vol- 
untas: International Journal of Voluntary and NonProfit Organizations, 14(2), 189-203.

Lindbeck, A., \& Snower, D. (1988). The insider outsider theory of employment and unemployment. Cambridge: The MIT Press.

Marshall, T. H. (1950). Citizenship and social class and other essays. Cambridge: Cambridge University Press.

Marshall, T. H. (1977). Class, citizenship and social development. Chicago and London: University of Chicago Press.

Marshall, T. H. (1981). The right to welfare and other essays. London: Heinemann.

McCrone, D., \& Bechhofer, F. (2008). National identity and social inclusion. Ethnic and Racial Studies, 31(7), 1245-1266.

Ogg, J. (2005). Social exclusion and insecurity among older europeans: The influence of welfare regimes. Ageing \& Society, 25(1), 69-90.

Ong, A. (2005). Citizenship. In D. Nugent \& J. Vincent (Eds.), A companion to the anthropology of politics (pp. 55-68). Oxford: Blackwell.

Parsons, T. (1994). Full citizenship for the Negro American: A sociological problem. In B. Turner \& P. Hamilton (Eds.), Citizenship: Critical concepts (pp. 139141). London and New York: Routledge.

Piller, I., \& Takahashi, K. (2011). Linguistic diversity and social inclusion. International Journal of Bilingual Education and Bilingualism, 14(4), 371-381.

Putnam, R. (2000). Bowling alone: The collapse and re- vival of American community. New York: Simon and Schuster.

Schuller, T. (2007). Reflections on the use of social capital. Review of Social Economy, 65(1), 11-28.

Soutphommasane, T. (2014, July 11). Are Asian Australians Trapped under a bamboo ceiling? Opinion article. The Guardian. Retrieved from https://www. theguardian.com/commentisfree/2014/jul/11/are-a sian-australians-trapped-under-a-bamboo-ceiling

The World Bank. (2007). Social exclusion and the EU's social inclusion agenda: Paper prepared for the EU8 social inclusion study. Retrieved from http://site resources.worldbank.org/INTECONEVAL/Resources/ SocialExclusionReviewDraft.pdf

Turner, B. (1993). Citizenship and social theory. London: SAGE Publications.

Valtonen, K. (2001). Cracking monopoly: Immigrants and employment in Finland. Journal of Ethnic and Migration Studies, 27(3), 421-438.

Weber, M. (1978). Economy and society: An outline of interpretive sociology. Berkeley and Los Angeles: University of California Press.

Weedon, K. (2002). Why do some occupations pay more than others? Social closure and earnings inequality in the United States. American Journal of Sociology, 108(1), 55-101.

Woolcock, M., \& Narayan, D. (2000), Social capital: Implications for development theory, research and policy. World Bank Research Observer, 15(2), 225-249.

\section{About the Author}

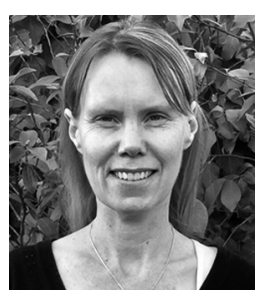

Juliet Pietsch is Associate Professor at the School of Politics and International Relations, Australian National University. Her research focus is in the area of public opinion, immigration politics and the political integration of migrants and ethnic minorities in Australia. 


\section{Appendix}

Table A.1. Coding of variables for Table 5 and Table 6.

\begin{tabular}{|c|c|}
\hline Variable & Scoring \\
\hline Income & 12-point scale, Low Income=1, High Income=12 \\
\hline \multicolumn{2}{|l|}{ Birthplace } \\
\hline South-Asia & Southern and Central Asia $=1$, Else $=0$ \\
\hline North-East Asia & North-East Asia=1, Else $=0$ \\
\hline South-East Asia & South-East Asia $=1$, Else $=0$ \\
\hline Southern and Eastern Europe & Southern and Eastern Europe $=1$, Else $=0$ \\
\hline \multicolumn{2}{|l|}{ Reference Category is North-West Europe } \\
\hline Ancestry of Parent 1 Southern and Central Asia & Southern and Central Asia $=1$, Else $=0$ \\
\hline North-East Asia & North-East Asia $=1$, Else $=0$ \\
\hline South-East Asia & South-East Asia $=1$, Else $=0$ \\
\hline Southern and Eastern Europe & Southern and Eastern Europe $=1$, Else $=0$ \\
\hline \multicolumn{2}{|l|}{ Reference Category is North-West Europe } \\
\hline \multicolumn{2}{|l|}{ Ancestry of Parent 2} \\
\hline Southern and Central Asia & Southern and Central Asia $=1$, Else $=0$ \\
\hline North-East Asia & North-East Asia $=1$, Else $=0$ \\
\hline South-East Asia & South-East Asia $=1$, Else $=0$ \\
\hline Southern and Eastern Europe & Southern and Eastern Europe $=1$, Else $=0$ \\
\hline \multicolumn{2}{|l|}{ Reference Category is North-West Europe } \\
\hline \multicolumn{2}{|l|}{ Language Spoken at Home } \\
\hline Southern Asian Languages & Southern Asian Languages $=1$, Else $=0$ \\
\hline Eastern Asian Languages & Eastern Asian Languages $=1$, Else $=0$ \\
\hline South-East Asian Languages & South-East Asian Languages $=1$, Else $=0$ \\
\hline Southern European languages & Southern European languages $=1$, Else $=0$ \\
\hline Northern European Languages & Northern European Languages excl. English=1, Else $=0$ \\
\hline \multicolumn{2}{|l|}{ Reference Category is English } \\
\hline \multicolumn{2}{|l|}{ English Proficiency } \\
\hline Very Well or Well & Very Well, Well=1, Not Well, Not at All=0 \\
\hline \multicolumn{2}{|l|}{ Timing of Arrival } \\
\hline Arrived 2000 or before & Arrived 2000 or before, Else $=0$ \\
\hline Arrived 2001-2005 & Arrived 2001-2005, Else $=0$ \\
\hline \multicolumn{2}{|l|}{ Reference Category is Arrived 2006-2011 } \\
\hline \multicolumn{2}{|l|}{ Background } \\
\hline Age & $1=18-24,2=25-29,3=30-34,4=35-39,5=40-44,6=45-49$ \\
\hline & $\begin{array}{l}7=50-54,8=55-59,9=60-64,10=65-69,11=70-74,12=75-79, \\
13=80-84,14=85 \text { and over. }\end{array}$ \\
\hline Education & $\begin{array}{l}\text { Certificate }=1 \text {, Diploma }=2, \text { Bachelor's Degree }=3, \\
\text { Graduate Diploma }=4 \text {, Postgraduate Degree }=5 \text {. }\end{array}$ \\
\hline
\end{tabular}

